\title{
Aurora Borealis is an Inspiration to the performance of Nordic
}

\section{Economies?}

\author{
Manuel Carlos Nogueira ${ }^{1, *}$ and Mara Madaleno ${ }^{2}$ \\ 1 Faculty of Economic and Business Sciences, University of Vigo, 36310 Vigo, Spain \\ 2 GOVCOPP-Research Unit in Governance, Competitiveness and Public Policy, Department of \\ Economics, Management, Industrial Engineering and Tourism (DEGEIT), University of \\ Aveiro, 3810-193 Aveiro, Portugal \\ * Correspondence: manuel.carlos.cunha.nogueira@uvigo.es
}

\begin{abstract}
The Nordic countries are practically always well positioned in the main international economic, social and sustainability indices and recommending the scientific literature that the variables that these indices intend to measure translate into sustainable economic growth, with this unprecedented empirical study we intend to verify through the ARDL methodology for space temporal 2004 -2018 if the maintenance of high scores in these indexes translates into effective economic growth. The ARDL methodology has the advantage of giving us short- and long-term coefficients. Using four of the main international indices, we conclude that for Nordic countries for economic growth, economic freedom is of no significance and business-friendly regulation is the most important variable. A fundamental discovery in our study (in which Granger's Causality complements the ARDL methodology) is that these countries have been able to adapt perfectly to the globalization process and that entrepreneurship has worked as an important contribution to the continued economic and social success of these countries, allowing them to continue to enjoy their "Nordic Welfare States" in these uncertain and troubled times. These variables have contributed to its economic and social sustainability.
\end{abstract}

Keywords: economic growth; globalization; sustainability; ease of doing business; entrepreneurship; economic freedom; Nordic countries.

\section{Introduction}

The Nordic countries are culturally homogeneous, relatively wealthy, have an efficient, productive, and strong public sector, while enjoying a culture of institutional cooperation that defends both public and private interests as well as acting quickly [1]. The socalled Nordic model that has brought such success to these countries is based on three key and unique factors: 1) Ancestral political traditions that are exceptionally egalitarian and democratic; 2) Generous social states; 3) Exceptional labor market policies and labor relations where spirits of cooperation are widely accepted by companies, workers, associations, and unions [1]. The contested contests that in other countries are limited only to protest and demand instead of producing, in the Nordic countries cooperation is the most important intending to find the best solutions for all interested parties, benefiting from these cooperative attitudes both employers and workers. In geographic terms, despite being countries with a large territorial extension (except Iceland), they have a small population but benefit from innumerable natural resources, which have been managed sustainably [1].

The great success of the Nordic countries has its origin in remote times and is called social trust in institutions, politicians, governments, and the judicial system. Social trust 
is the most important resource and helps to promote investment, entrepreneurship, creates jobs, allows economic freedom and countless benefits that stimulate the economy and society [2]. The Nordic citizens believe that public agents work fairly and transparently, with a high degree of integrity, and this causes positive effects and economic successes, which spill over into the entire economy causing economic development [2].

The Nordic countries are characterized by a highly virtuous cycle in which several important institutions and indicators work in unison: democracy, generous social status, low crime, little corruption, social trust, free press, high and free schooling, the strong role of civil society and social cohesion [3].

With Nordic countries being ranked first in practically all the main international indexes, the main objective of this work is to conclude, with the use of empirical models, if through these excellent positions in these rankings there is a significant relationship between these positions and economic growth and which of these indexes mostly impact this growth. The aim of this paper is hence to fill the identified research gap by conducting a quantitative analysis of the determinants in the five Nordic countries, for the years 2004 to 2018, concerning the relationship between economic freedom, ease of doing business, globalization, entrepreneurship, and economic growth. Another added value of this paper is that for what we know it is the first time that for the Nordic countries these variables are used jointly.

In empirical terms, we first used the ARDL model and obtained the coefficients for the short and long-term coefficients. After estimating the VAR model, we performed the Granger Causality Test. Through the results obtained in this test, we validated almost all the results obtained in the ARDL model and we could still conclude that there are several important bidirectional and unidirectional relationships between the independent variables of the ARDL model.

The outline of the study is as follows. In Section 2 we briefly refer to the relevant literature. Section 3 shows the data, variables description, and statistics. Section 4 presents the empirical analysis for total data using the ARDL methodology and Granger's Causality after resorting to VAR modeling and Section 5 the respective discussion. Finally, in Section 6 we conclude the paper.

\section{Literature review and hypothesis formulation}

\subsection{Economic freedom}

The concept of economic freedom is associated with the liberalism that emerged in Europe in the 18th century. Economic liberalism argues that the state should not intervene in the economy, allowing the private initiative to proliferate. More capable and betterprepared individuals, through their merit, will make the economy flourish. Each person is responsible for it, because the freedom of people to decide and control their lives improves living standards and, therefore, the state must be to intervene as little as possible in people's lives [4].

For this economic theory, if government actions go beyond the minimum necessary level, imposing a series of restrictions on economic activities, can cause diversions of resources and initiatives by companies, leading in the end to the decline of the country's economic growth. Proponents of this theory argue that economic freedom causes more and better economic growth [5].

Much scientific research has been carried out on economic freedom, namely on the effect that this freedom has on economic growth. As economies usually work best without outside interference, most studies conclude that increased economic freedom tends to cause higher rates of economic growth [6].

The neoclassical economic growth models based only on production functions that only consider labor, capital, and technology, are incomplete because they do not include a very important determinant, economic freedom [7].

When counting the number of studies that reach empirical evidence of the existence of positive effects between economic freedom and economic growth, the authors report that more than 260 studies concluded that economic freedom positively impacts economic 
growth, as well as provoking advances in economic growth, living standards or increases happiness [7].

Although economic freedom is important for economic growth, it does not mean that increasing economic freedom in general terms promotes that growth. This conclusion is drawn by the fact that there are some dimensions of the index that do not present statistical significance or even a negative sign, in which case the important dimensions should be selected [7].

Free trade facilitates the flow of goods and services worldwide and allows adding value to local economies and contributing to global economic growth. In the last decades, free trade has been greatly increased through preferential trade agreements that have been established, and the resulting benefits have been increasingly recognized by all stakeholders [8]. Clear defenders of free trade, these authors, end their argument by stating that this freedom has been the basis of economic advancement and the expansion of global markets that have proven to be a powerful engine for growth and a key factor in the global fight against poverty. Freer economies also lead in terms of innovation [8].

Recently, in an empirical analysis for 43 European countries between 1995 and 2014, the authors concluded that economic freedom has a positive effect on economic growth, with increases in economic freedom scores positively impacting said growth [9]. Dissonant to most researchers who find positive correlations between economic freedom and economic growth, a small number of researchers argue that high levels of economic freedom can be detrimental to economic growth. The complete or high removal of protectionist barriers exposes domestic companies to competition that is difficult to match. This situation is more worrying in developing countries, due to their stages of development [10].

But economic freedom was not just analysed in terms of the effects it may or may not have on economic growth. In seeking to analyse whether a country's competitiveness is influenced by economic freedom and discovering the nature of this influence, it was found that countries considered highly free in economic terms are also seen as highly competitive. The standard of living, employment rate, productivity, trade balance and national attractiveness are directly determined by economic freedom [11].

Nordic countries generally have large budget expenditures and large governments, which could create obstacles to business activity, but these countries enjoy peaceful coexistence between governments and increasing degrees of economic freedom and thus achieve economic growth [12]. In Nordic countries where the well-being mentality is implemented, economic freedom is considered a key element to achieve economic sustainability goals [13]. These authors, using an economic freedom index as one of the dependent variables, also state that there is a relationship between the well-being mentality and sustainable development.

Given the review of the literature in general terms and, to the Nordic countries on the effects of economic freedom on the growth of the economy, we formulate the following hypothesis to be tested empirically.

Hypothesis 1: There is a positive and significant relationship between economic freedom and economic growth?

\subsection{Ease of Doing Business}

There are countless studies on the relationship between regulation that makes it easier to do business and its effects on economic growth. In general, the conclusions are practically unanimous, in which countries with better regulations are growing faster than others. In countries with lower income, the entry of companies is more expensive and more bureaucratic. Countries with higher regulations have higher corruption, as well as a larger unofficial economy [14].

Countries with democratic governments have less regulation for the constitution of companies. Regarding rules, these authors consider that they provide environments where new participants with innovative and motivating ideas can start a business easily and where highly productive companies can invest, expand, and create jobs [14]. On one hand countries that reduce regulatory burdens tend to achieve higher business growth 
rates. On the other hand, countries that position themselves in the last quartile of the ranking, if they managed to move to the first quartile, could add two percentage points to their economic growth, which would represent a large increase in terms of growth [14].

Elaborated policies that promote the ease of doing business (EDB) are a determinant for the level of income per capita [15]. The classification in the Doing of Business Index of legal and political-institutional quality is an important explanatory variable for economic growth, which has been empirically tested in several studies. Em relação ao valor do Índice, foram encontradas evidências da existência de relação significativa entre aumentos do índice e o crescimento econômico per capita, tanto no curto quanto no longo prazo. Os resultados obtidos sugerem que os benefícios das reformas de política econômica são duradouros. Esse índice pode ser uma ferramenta de promoção do desenvolvimento econômico, uma vez que uma melhoria no ambiente de negócios pode contribuir para um maior crescimento econômico [15].

When being used EDB indicators as business regulation level proxies for 172 countries between 2006 and 2010, significant statistical evidence was found between business regulatory reforms and economic growth. Each additional reform is associated, on average, with an increase of $0.15 \%$ in economic growth, and the countries that more reforms in terms of business regulation carried out before the economic and financial crisis of 2008, more easily mitigated the effects of this crisis [16].

For seven Balkan countries, evidence was found that when a country rises in the ranking of the ease of doing business in the Balkans, economic growth increases by 0.72 percentage points. Considering the ten dimensions of the Doing Business Report, the one that most impacts economic growth is "Getting credit", which can promote economic growth per capita by 0.77 percentage points [17].

The Doing Business Report has numerous advantages in measuring and allowing comparisons between countries and temporal evolution of important business variables, as measuring costs, times, records, credit, contracting, imports, and exports, etc [18].

The higher the position of a country in the ranking, the more favourable its regulatory environment at the business level, that is, the easier it is to create and develop a business.

This World Bank index has become a widely used tool for measuring the quality of business regulations around the world and underlies the idea that complicated and unnecessary regulations stifle activity. More favourable business environments are achieved by removing these regulations [18]. Other authors, in an empirical study, found that there is a positive and significant relationship between the Ease of Doing Business scores and the countries' socioeconomic wealth [19]. The more obstacles to free trade a government introduces in his country, the lower its level of wealth. Some studies conclude that there is a positive effect on GDP growth per capita, as well as on foreign direct investment (FDI) flows and exports, when there are improvements in regulatory quality at the business level, thus reducing, among other factors, the so-called costs of the transaction [20].

But the relationship between Ease of Doing Business and economic growth is not always empirically verified, or any variable that can promote this growth in all countries of the world, since significant correlations between the index and FDI have already been found, but only for middle-income countries, but in the case of low-income countries, these correlations are no longer seen [18], but also these correlations were insignificant for the case of developing countries [21].

Considering the EDB scores and as the business environment is heterogeneous between countries, the positive effects overflow from developed countries to developing countries, with the so-called spillover effects occurring [22].

For the Nordic countries, an efficient public sector plays an important role in economic growth [23]. The removal of barriers and bureaucracies in the economy raises issues of resistance on the part of workers, but the compensation in economic terms is quite remarkable and rewarding for these countries [23].

Regarding the importance of the variable that measures business-friendly regulations, the Nordic countries were advised to reduce barriers and administrative bureaucracies in the acts of setting up companies, since they are harming the economic growth [24]. 
On the other hand, following the long tradition of corporate movements, the existence of several reflection clubs in Nordic countries including in business terms and financed by business associations, which are dedicated to spreading liberal ideas and policies and are also designed to adopt business-friendly lines [25].

Based on the literature review in general terms and specifically for the Nordic countries and for the variable that measures the existence of business-friendly regulations, we formulate the following working hypothesis:

Hypothesis 2: Removing or simplifying administrative or legal barriers, that facilitate business deals, positively and significantly affect economic growth?

\subsection{Globalization}

In terms of scientific literature, globalization is usually divided into economic, political, and cultural terms and consists of the increasing integration of peoples. It is characterized by the widening of relations between peoples, and certainly, no one can say when the globalization process has started. In economic terms, globalization is seen as a growing integration of goods and capital markets around the world, as well as the lifting of protectionist barriers to trade and investment [26].

Because globalization does not have a direct measurement, proxies are also required for this variable. The globalization index developed by the KOF Swiss Economic Institute is one of the most used [26]. In the most recent decades, economists began to pay more attention to the effects of globalization, reaching the existence of numerous special editions of journals dedicated to this theme, as well as the launch of several books. In almost all studies, the conclusions were similar, in which there are positive effects on economic growth brought about by globalization [26]. The Globalization Economic Index indicator was divided into three dimensions, namely, economic with a weight of $37 \%$ in the final score, politics with a weight of $26 \%$, and social with a weight of $37 \%$ [27]. Two years later, the dimensions now contribute equally to the final value of the scores, but that as a whole group more than 40 indicators [27].

Several authors have already found evidence of the benefits that globalization has on Nordic countries' economies. The Nordic countries benefited from the expansion of the world economy in the 1950s and 1960s, due to their high degree of openness to the outside. After the crisis of the seventies, this author states that the Nordic countries invested in the education, health, and safety of their citizens, which allowed them to relaunch their economies [28].

Also using the KOF index as a proxy for globalization, the Nordic countries had growth rates of their GDPs per capita higher than those presented by the most developed European countries and by the Anglo-Saxon countries, despite presenting a continuous increase in their openness to the outside [16]. Although the loss of social well-being has traditionally been associated with globalization, in the case of Nordic countries this has not occurred. This proves that social well-being and globalization are compatible, as well as the existence of compatibility between globalization and the high tax burden that supports Nordic social well-being [12].

Still, concerning globalization and consequent competition, that it is an opportunity and not a threat, which has been the basis of the economic growth of the Nordic countries. Small economies like the Nordic ones need to develop and benefit from international contacts that come from globalization [23]. In the case of Denmark, this country has adapted to globalization as a survival strategy [29]. The adaptation was successful, achieving Denmark the maintenance of the Scandinavian social welfare model [29]. Although the Nordic countries are small economies, they are highly open to the outside and were able to exploit the advantages of globalization, largely due to their levels of productivity [30].

Given the literature review carried out for the case of globalization, for the Nordic countries, we formulate the following hypothesis in the question form, to be tested empirically.

Hypothesis 3: Are Nordic economies knowing how to take advantage of globalization to grow economically, without affecting their traditional economic and social model? 


\subsection{Entrepreneurship}

Entrepreneurial activity supports economic growth and causes competition and innovation in the economy [31]. For the top 50 in the ranking of the Global Competitiveness Index innovation was one of the pillars of the GCI that most contributed to the economic growth of these 50 countries in an extended period [32].

In the Nordic countries, special attention is paid to entrepreneurship, and an organization has been created between these countries which, in addition to supporting and encouraging innovation projects, also pays attention to entrepreneurship and entrepreneurship among women (Nordic Innovation). These countries provide to citizens in need, high economic and social support, which could discourage entrepreneurship, but because they enjoy high levels of education, it provides entrepreneurs with an abundant highly qualified workforce, which facilitates innovation and entrepreneurship.

In the Nordic countries, an increase in entrepreneurship began to be seen, largely because of the entrepreneurial streak of the children of immigrants. It is very common for the second generation of immigrants to follow entrepreneurial careers facilitated by their high schooling [33]. Still, on the rates of entrepreneurs the Nordic countries present low rates in comparison with other European countries or the USA [24]. The lack of entrepreneurial capacity, the lack of business skills, the lack of specific financing, and the aversion to risk, can help explain the Nordic people's lack of appetite for entrepreneurship [24]. Perhaps it is because of this lack of appetite of the Nordics, that the second generations of immigrants are pursuing entrepreneurial careers, thus taking the place that the natives do not want [33].

In a reflection on entrepreneurship in the Nordic countries leaving some important work paths, education emerges as preponderant for entrepreneurship, mainly in the training of young people, increasing their entrepreneurial skills to succeed in the business world. When analysing the existing entrepreneurship education strategies in the Nordic countries, these countries were found to have adequate strategies (although they could be improved) and yet that they should foster entrepreneurship programs across the different Nordic countries. Perhaps this reality, which was already verified in 2012, has contributed to the importance of entrepreneurship in economic growth [34].

Citing similar conclusions obtained in other studies and for the Nordic countries between 2004 and 2013, concludes that there are positive and significant relationships between entrepreneurial activity and GDP per capita [24].

Studying factors related to entrepreneurship and innovation that influence economic growth, using the quadruple helix model, and the traditional north-south comparison, conclude that the northern European countries (mostly Nordic), present better results in innovation and entrepreneurship than the countries of the South, with significant differences for the economy [35].

Considering these previous findings and concentrating attention on the Nordic countries, we formulate the last hypothesis that will also be tested empirically.

Hypothesis 4: There is a positive and significant relationship between entrepreneurial activity and GDP per capita in Nordic countries?

\section{Data, variables, and statistics}

The sample used in this study comprises the period between 2004 and 2018 for the Nordic countries. To be able to use the ARDL methodology, we calculate the averages of the variables of the 5 countries for each year, thus obtaining a time series composed of all variables. Table 1 shows the variables used in the empirical analysis, units of measurement, and the source of data. Table 2 expresses the average of the variables for each country considered and Table 3 presents the main descriptive statistics. 
As shown in Table 2, in terms of average GDP per capita in purchasing power parities, the highest figure is found in Norway. Conversely, it is in Finland where the average value of this variable is the lowest.

Table 1 - Variable definition and data sources

\begin{tabular}{cccc}
\hline Variable & Definition & Unit & Source \\
\hline GDPpct & Gross domestic product on purchasing power parity per capita & USD & World Bank \\
EFW & in year $t$ & Index & Fraser Institute \\
EDB & Economic Freedom of the World in year $t$ & Index & World Bank \\
KOFt & Ease of Doing Business in year $t$ & Index & KOF Swiss Economic \\
GEIt & Globalization Economic Index in year $t$ & Institute & Gedi Institute \\
\hline
\end{tabular}

Source: Authors' elaboration.

Regarding economic freedom, the highest average value is found in Denmark and the lowest in Norway. Concerning the ease of doing business through favourable regulatory environments, the highest average value is found in Denmark and the lowest in Finland.

Table 2 - Average of Variables for Each Nordic Country (2004-2018)

\begin{tabular}{lccccc}
\hline Country & GDPpc & EFW & EDB & KOF & GEI \\
\hline Denmark & 44509 & 7.97 & 82.87 & 83.09 & 50.98 \\
Finland & 40261 & 7.84 & 80.26 & 86.42 & 41.92 \\
Norway & 59375 & 7.65 & 80.97 & 84.89 & 57.12 \\
Sweden & 44117 & 7.72 & 81.18 & 88.73 & 52.79 \\
Iceland & 44369 & 7.41 & 77.47 & 70.00 & 74.88 \\
\hline
\end{tabular}

Source: Authors' calculation

Regarding the variable that measures economic globalization, the highest average value is found in Sweden and the lowest in Denmark. The highest average index of entrepreneurship occurs in Norway and the lowest in Finland.

Table 3 contains the main descriptive statistics of the sample used and Pearson's correlation coefficients. To obtain accurate results from the empirical analysis, we also consider the problem of multicollinearity. Pearson's correlation test applied to our variables showed that there is no multicollinearity between the variables considered, considering that we used the value of 0.80 as a limit, of some renowned econometricians, although there is no absolute consensus on this maximum value [36].

Table 3 - Main descriptive statistics and correlations

\begin{tabular}{lccccccccc}
\hline & Maximum & Minimum & Average & St. deviation & GDPpc & EFW & EDB & KOF & GEI \\
\hline GDPpc & 59245 & 35208 & 46678 & 6233 & 1.000 & -0.015 & 0.763 & 0.107 & -0.227 \\
EFW & 78.55 & 76.62 & 78.00 & 0.6616 & & 1.00 & -0.063 & 0.298 & 0.248 \\
EDB & 80.02 & 77.24 & 79.38 & 0.8001 & & & 1.000 & -0.014 & -0.350 \\
KOF & 82.08 & 77.51 & 81.04 & 1.5283 & & & & 1.000 & 0.041
\end{tabular}




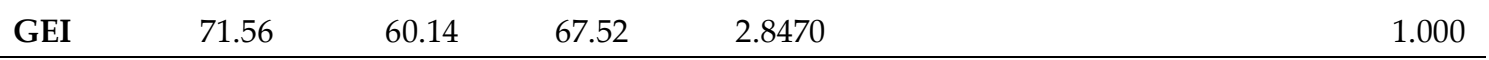

Source: Authors' calculation. Variables description in table 1.

\section{Empirical Analysis}

4.1 Model Specification and estimation according to the ARDL methodology

The ARDL (Autoregressive Distributed Lag) cointegration methodology allows testing the existence of a relationship between a dependent variable and a set of regressors, in case there is no certainty about the stationarity of the regressors. The proposed tests allow testing the significance of the lagged levels of the variables in a univariate equilibrium correction mechanism. In terms of economic series, that cointegration becomes the solution to determine the long-term relationships in the time series [37 - 40].

As most time series is not stationary, that is, they present large divergences from their mean over time, econometrics began to give importance to the problem of cointegration, which detects the presence of a state of steady equilibrium between the variables. If the variables do not cointegrate, then spurious regression problems are seen, and the results become meaningless [37 - 40].

The ARDL approach has a considerable number of advantages over traditional cointegration. In addition to being more flexible and more rigorous in the results when I (0) or I (1), its implementation and interpretation is simply because it is just an equation. Unlike other methods, it can be used in which the variables assume different lags and are quite reliable in small samples. It also provides us with impartial long-term estimators and finally, autocorrelation and endogeneity are adequately addressed [41].

The ARDL cointegration methodology, in addition to testing the dynamic interactions between variables, also examines the short and long-term relationships between variables. This methodology also has two additional advantages, on the one hand, in the presence of endogeneity, the model has impartial coefficients in addition to being efficient and consistent in small samples [42].

The ARDL cointegration technique is one of the greatest discoveries of the late 20th century in terms of time series analysis, and it has the advantages of not requiring a pretest of unit root unlike other techniques in the identification of cointegration vectors. However, these authors warn if the steps of the methodology are not followed correctly, it can cause inconsistent and unrealistic estimates to be obtained when making forecasts [43].

Taking into account the ARDL methodology, we will specify our models that intend to study empirically the existence or not of long-term relationships between the value of GDP per capita and a set of four renowned and internationally recognized indexes that intend to measure as many other concepts, that in terms of theoretical and empirical literature tend to cause economic growth for Nordic countries between 2004 and 2018. For bound tests of cointegration the ARDL model used in our study is given in equation (1) [40].

\section{Results}

This section may be divided by subheadings. It should provide a concise and precise description of the experimental results, their interpretation, as well as the experimental conclusions that can be drawn.

$$
\begin{gathered}
\Delta G D P p c_{t}=a_{0}+\sum_{i=1}^{m} \alpha_{1} i \Delta G D P p c_{t-1}+\sum_{i=1}^{m} \alpha_{2} i \Delta E F W_{t-1}+\sum_{i=1}^{m} \alpha_{3} i \Delta E D B_{t-1}+\sum_{i=1}^{m} \alpha_{4} i \Delta K O F_{t-1}+\sum_{i=1}^{m} \alpha_{5} i \Delta G E I_{t-1}+ \\
\beta_{1} E F W_{t-1}+\beta_{2} E D B_{t-1}+\beta_{3} K O F_{t-1}+\beta_{4} G E I_{t-1}+\varepsilon_{t}
\end{gathered}
$$

4.2 Analysis of the stationarity of variables

Provided the estimation using the ARDL methodology, it is not necessary to measure the stationarity of the variables $[39,40]$. Even so, we decided to carry out two-unit root 
tests for the sake of knowing what the lag order is for that the variables obtain stationarity. We performed the Augmented Dickey-Fuller (ADF) and Kwiatkowski-Phillips-SchmidtShin (KPSS) tests, the results of which are shown in Table 4.

The ADF test is based on the null hypothesis that the series is stationary against the alternative hypothesis that the series has a unit root. In case of $t_{\text {stat }}<t_{\text {crit }}$ we do not reject the null hypothesis, which means that the series is stationary. The KPSS test uses the Lagrange Multiplier (LM) statistic, and the test statistic is compared with the critical value for the desired significance level.

Table 4 - Unit root tests

\begin{tabular}{|c|c|c|c|c|}
\hline \multirow[b]{2}{*}{ Variables } & \multicolumn{2}{|c|}{ ADF Test } & \multicolumn{2}{|c|}{ KPSS Test } \\
\hline & Level I(0) & First diff. I(1) & Level I(0) & First diff. I(1) \\
\hline \multirow[t]{2}{*}{ GDPpc } & 0.647 & 0.108 & 1.303 & $0.134^{* * *}$ \\
\hline & $(0.515)$ & $(0.012)^{* *}$ & & \\
\hline \multirow[t]{2}{*}{ EFW } & $0.026^{* * *}$ & - & $0.115^{* * *}$ & - \\
\hline & $(0.04)$ & & & \\
\hline \multirow[t]{2}{*}{ EDB } & $0.508^{* *}$ & - & 0.771 & $0.158^{* * *}$ \\
\hline & $(0.015)$ & & & \\
\hline \multirow[t]{2}{*}{$\mathrm{KOF}$} & 0.160 & -0.023 & $0.273^{* * *}$ & - \\
\hline & $(0.144))$ & $(0.006)^{* * *}$ & & \\
\hline \multirow[t]{2}{*}{ GEI } & $0.009^{* * *}$ & - & $0.333^{* * *}$ & - \\
\hline & $(0.013)$ & & & \\
\hline
\end{tabular}

$*{ }^{* *}, \mathrm{e}^{* * *}$ indicates $10 \%, 5 \%$ e $1 \%$, respectively significance level

Source: Authors' calculation. See variable symbols meaning in Table 1.

Through the results shown in Table 4, we verified that all variables obtain stationarity at most until the first differences. In this way and although it is not necessary to test stationarity to use the ARDL model, we are aware that all variables assume maximum stationarity until the first differences.

4.3 Cointegration tests and bonds tests

Testing cointegration is a necessary step to establish whether a model empirically exhibits significant long-term as well as short-term relationships [43].

Thus, using the cointegration tests of the ARDL model, we obtain the ideal selection of the lags and test the possible long-term relationship between the variables of the model. The best known of these tests is the AIC criterion that quantifies the quality of a statistical model, by calculating the amount of information that a model loses, seeking to obtain the best model. The choice must fall for the lower AIC score, because in this case the less information will be lost, the better its quality will be [44].

Table 5 - Cointegration tests

\begin{tabular}{lcccc}
\hline \multicolumn{5}{c}{ Akaike Criteria (AIC) } \\
\hline \multicolumn{1}{c}{ Variables } & Lag 0 & Lag 1 & Lag 2 & Lag 3 \\
\hline GDPpc & -8.495 & $-8.891^{*}$ & -8.728 & -8.652 \\
EFW & -9.954 & $-10.37^{*}$ & -10.21 & -9.681 \\
EDB & -7.693 & $-8.029^{*}$ & -7.923 & -7.817
\end{tabular}




\begin{tabular}{lllll} 
KOF & $-5.940^{*}$ & -5.794 & -5.616 & -5.548 \\
GEI & $-9.545^{*}$ & -9.364 & -9.322 & -9.124 \\
\hline
\end{tabular}

Source: Authors' calculation. Variables description in table 1.

Through the results identified for the analysis of cointegration by the AIC criterion and which are shown in table 5, the ideal ARDL model to be estimated will have to be based on a lag for the GDPpc, EFW, and EDB variables and the remaining zero lag variables. Thus, we do not reject the null hypothesis of the non-existence of cointegration to a significance level of $1 \%$, which means the existence of long-term relationships between the independent variables and the dependent variable, that is, lags $\left(\begin{array}{llll}1 & 1 & 1 & 0\end{array}\right)$.

Regarding the F statistic calculated for the cointegration order chosen using the AIC criterion, we found that this statistic is 30.87 , as the upper limit of the critical $\mathrm{F}$ for the $5 \%$ significance level is 4.01 . So, we reject $\mathrm{H} 0$ for the non-existence of a long-term relationship between at least one independent variable and the dependent variable GDP per capita, which again confirms the existence of these relationships.

Because of the results obtained through the cointegration tests and the bounds tests, the estimation of the ARDL model through the correction of errors seems to be the most appropriate.

4.4 Long-term coefficients and short-term dynamics based on the ARDL model

Once the existence of long-term relationships between the dependent variable and at least one dependent variable is verified, we will estimate through the ARDL models the respective coefficients, as well as the short-term dynamics. To better interpret the coefficients, we use a log-log model specification, which also has the advantage of obtaining elasticities.

Table 6 - Results of long-term ARDL estimates

\begin{tabular}{clccc}
\hline & \multicolumn{2}{l}{ Model 1 ARDL (1 11100$)$} & \multicolumn{2}{c}{ Model 2 ARDL (1 1 1 0) } \\
\hline Variables & Coefficients & p-value & Coefficients & p-value \\
\hline EFW & 0.2971 & 0.483 & - & - \\
EDB & $4.1473^{* * *}$ & 0.000 & $4.4571^{* * *}$ & 0.000 \\
KOF & $2.1057^{* *}$ & 0.035 & $2.0471^{* *}$ & 0.012 \\
GEI & $0.0154^{*}$ & 0.096 & $0.0784^{*}$ & 0.081 \\
\hline
\end{tabular}

$*, * *, e^{* * *}$ indicates $10 \%, 5 \%$ e $1 \%$, respectively significance level

Source: Authors' calculation. Variables description in table 1.

Through the results of long-term ARDL estimates (Table 6), we can see that there are significant long-term relationships between business-friendly regulations, globalization, and entrepreneurship, which demonstrates the importance of these variables in GDP growth per capita in Nordic countries. The economic freedom variable is not statistically significant.

Regarding the results of short-term dynamics (Table 7), none of the variables has statistical significance. The error correction equations (also called "adjustment spirit") in the two models show statistical significance for levels normally considered, which again shows the existence of cointegration between the short and the long term between the independent variables and the dependent variable.

Table 7 - Results of short-term dynamics 


\begin{tabular}{ccccc}
\hline & \multicolumn{2}{c}{ Model 1 ARDL (1 1 0 0) } & \multicolumn{2}{c}{ Model 2 ARDL (1 1 1 0) } \\
\hline Variables & Coefficients & p-value & Coefficients & p-value \\
\hline EDB & -0.6814 & 0.477 & -0.6847 & 0.358 \\
KOF & -0.8235 & 0.145 & -0.6324 & 0.278 \\
GEI & -0.0125 & 0.357 & -0.2895 & 0.358 \\
Ec (-1) & $-0.7814^{* *}$ & 0.027 & $-0.8134^{* * *}$ & 0.009 \\
\hline
\end{tabular}

$*, * *, e^{* *}$ indicates $10 \%, 5 \%$ e $1 \%$, respectively significance level

Source: Authors' calculation. Variables description in table 1

These coefficients also indicate the speed of annual adjustment towards equilibrium, with both models showing the effects of variables contributing to a higher persistence in economic growth, given that for model 1 , only $22 \%$ of economic growth adjusts in the year, and in model 2 this value is about $19 \%$.

4.5 Diagnostic and stability tests of the regression coefficients

The results in Table 8 allow us to verify that the models do not show serial correlation or heteroscedasticity. Regarding the CUSUMSQ stability tests, it appears that the two models are stable, given that they remain within the critical limits for the $5 \%$ significance level (Figure 1). In this way, we have guaranteed the robustness of the results [45].

Table 8 - ARDL diagnostic tests

\begin{tabular}{ccccc}
\hline & \multicolumn{2}{c}{ Model 1 } & \multicolumn{2}{c}{ Model 2 } \\
\hline Tests & Value & p-value & Value & p-value \\
\hline Durbin-Watson & 2.0380 & & 1.943 & \\
LM test Breusch-Godfrey & 1.6271 & 0.2795 & 1.8325 & 0.2571 \\
$\begin{array}{c}\text { White test to } \\
\text { Heterocedasticity }\end{array}$ & 13 & 0.3369 & 13 & 0.3369 \\
\hline
\end{tabular}

Source: Authors' calculation.

Figure 1 - CUSUM squared tests 

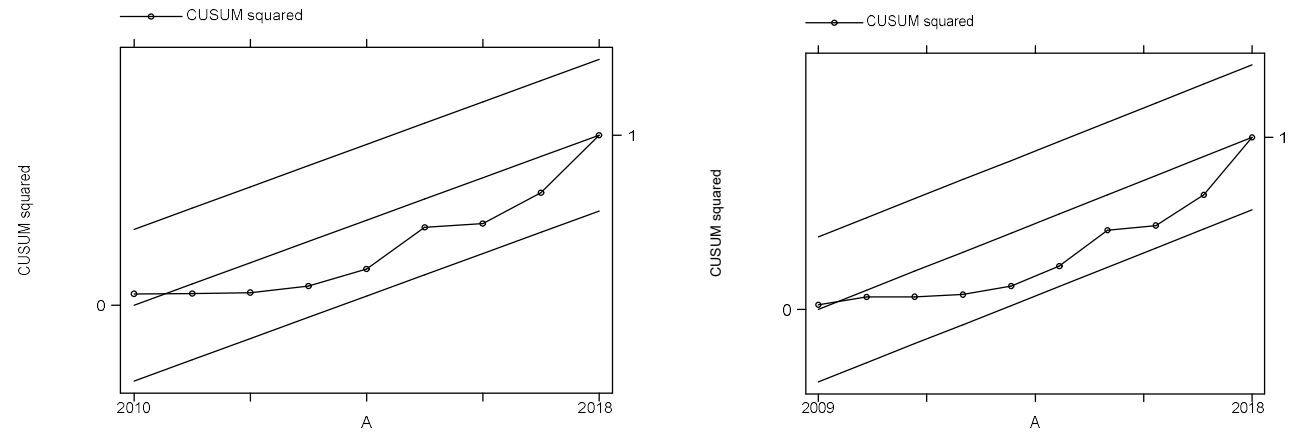

Source: Authors' elaboration.

\subsection{Granger Causality}

Causal tests became more widely used after the publication of an article in the journal Econometrica by the British econometrist Clive Granger. In this paper, this author assumes that the future cannot cause the present or the past, but the reverse can. For example, if event $A$ occurred in the past, event $B$ occurs in the present and $C$ will occur in the future, this may eventually mean that A causes B or C, but C does not cause B or A [46].

Granger's methodology is frequently used in the scientific literature of economics, to test temporal relations and changes in economic variables, that is, to verify the temporal precedence of one variable concerning the other.

Granger proposed a causality that uses autoregressive vector linear models (Vector Autoregressive Analysis - VAR), in which if a time series x (n) Granger causes another y (n), then the past knowledge of the first allows improving the predictability of the second. This is stated in this expression:

$$
x(n) \frac{\text { Granger }}{\text { Cause }} \rightarrow y(n)
$$

A fact considered important in this causality is that it has the property of symmetry, that is: $x(n) \frac{\text { Granger }}{\text { Cause }} \rightarrow y(n)$, does not imply that $y(n) \frac{\text { Granger }}{\text { Cause }} \rightarrow x(n)$, because there may be a unidirectional relationship, but not a bidirectional relationship.

In empirical terms, Granger's Causality is obtained through two regressions, namely those represented in equations (3) and (4).

$$
\begin{aligned}
& X_{t}=\sum_{j=1}^{m} \propto_{j} x_{t-j}+\sum_{j=1}^{m} \beta_{j} Y_{t-j}+\varepsilon_{t} \\
& Y_{t}=\sum_{j=1}^{m} \gamma_{j} y_{t-j}+\sum_{j=1}^{m} \emptyset_{j} x_{t-j}+\mu_{t}
\end{aligned}
$$

On what $\varepsilon_{t}$ and $\mu_{t}$ represent the so-called white noises that are not correlated and $\mathrm{m}$ being the upper temporal number of data considered. The validity of the series studied through Granger's causality is verified using Test F, where the null hypothesis of the coefficients is that, together $\sum_{j=1}^{m} \beta_{j}$ and/or $\sum_{j=1}^{m} \emptyset_{j}$ equal to zero as exposed in equation (4) [36].

$$
F=\frac{\frac{\left(S S S R_{R}-S S S R_{I R}\right)}{x}}{\frac{S S S R_{I R}}{n-k}}
$$


In the former, SSSR is the sum of squares of the residuals of the restricted regression; SSSIR the sum of squares of the residuals of the unrestricted regression; $x$ the number of lagged errors of variable $X ; n$ the sample size and $k$ the number of regressors estimated in the unrestricted regression including the constant.

Table 9 - Granger causality Wald tests

\begin{tabular}{|c|c|c|}
\hline Granger causality test in pairs & $x^{2}$ & p-value \\
\hline LnGDPPPP does not Granger cause LnEFW & 36.988 & $0.000^{*}$ \\
\hline LnGDPPPP does not Granger cause LnEDB & 10.069 & $0.007^{*}$ \\
\hline LnGDPPPP does not Granger cause LnKOF & 46.165 & $0.000^{*}$ \\
\hline LnGDPPPP does not Granger Cause LnGEI & 1.7756 & 0.412 \\
\hline All four variables do not cause Ln GDPPPP & 134.81 & $0.000^{*}$ \\
\hline LnEFW does not Granger cause LnGDPppp & 1.3411 & $0.531^{*}$ \\
\hline LnEFW does not Granger cause LnEDB & 21.714 & $0.000^{*}$ \\
\hline LnEFW does not Granger cause LnKOF & 9.4223 & $0.000^{*}$ \\
\hline LnEFW does not Granger Cause LnGEI & 32.786 & $0.000^{*}$ \\
\hline All four variables do not cause LnEFW & 54.383 & $0.000^{*}$ \\
\hline LnEBD does not Granger cause LnGDPppr & 38.341 & $0.000^{*}$ \\
\hline LnEDB does not Granger cause LnEFW & 14.549 & $0.001^{*}$ \\
\hline LNEDB does not Granger cause LnKOF & 5.3967 & 0.067 \\
\hline LnEDB does not Granger Cause LnGEI & 5.6908 & 0.058 \\
\hline All four variables do not cause LnEDB & 54.383 & $0.000^{*}$ \\
\hline LnKOF does not Granger cause LnGDPppp & 17.9483 & $0.000^{*}$ \\
\hline LnKOF does not Granger cause LnEFW & 22.987 & $0.000^{*}$ \\
\hline LnKOF does not Granger cause LnEDB & 14.548 & $0.001^{*}$ \\
\hline LnKOF does not Granger cause LnGEI & 37.619 & $0.000^{*}$ \\
\hline All four variables do not cause $\mathrm{LnKOF}$ & 207.24 & $0.000^{*}$ \\
\hline LnGEI does not Granger cause LnGDPPPp & 1.245 & 0.534 \\
\hline LnGEI does not cause Granger LnEFW & 11.501 & $0.003^{*}$ \\
\hline LnGEI does not cause Granger LnEDB & 16.161 & $0.000^{*}$ \\
\hline LnGEI does not cause Granger LnKOF & 2.0412 & 0.360 \\
\hline All four variables do not cause LnGEI & 48.946 & $0.000^{*}$ \\
\hline
\end{tabular}

Source: Authors' calculation.

*Indicates the rejection of the null hypothesis with signif. levels greater than 5\% (Granger, 1969).

If through the F Test the null hypothesis for equation (3) is rejected and it is not rejected for equation (4), there are indications that the series $y$ causes $x$ and not the other way around. If in turn, using the F test, the null hypothesis is rejected for both equations, it means that one can speak of a bidirectional relationship between the two series ( $\mathrm{x} \leftrightarrow \mathrm{y}$ ). Finally, if the F test does not reject the null hypothesis for both equations, then there is no evidence of causality between the two-time series.

The Granger Causality Test is performed according two hypotheses. 
Null hypothesis: The lagged variable does not cause the other variable.

Alternative hypothesis: The lagged variable causes the other variable.

The decision criteria: reject the null hypothesis if the p-value of $x^{2}$ statistic is $<0.05$.

Here in our case, after analysing the long-term relationship, we will use the Granger causality test to determine the potential causality between the variables. Given that as we verified that there is cointegration between the variables, it is to be expected that there are some unit or bidirectional and unidirectional causal relationships between the variables. To be able to perform the Granger Causality test, it will first be necessary to estimate the VAR model [47].

To evaluate the direction of causality between the study variables, Pairwise Granger causality was conducted on the variables and the results are presented in Table 9 below.

\section{Discussion}

Through the succession of tests carried out in the previous point, we are led to conclude that there are long-term relationships between at least one of the independent variables used and the dependent variable economic growth, for the Nordic countries and the period between 2004 and 2018. Still, in terms of the long term, all the coefficients assume a positive sign according to expectations.

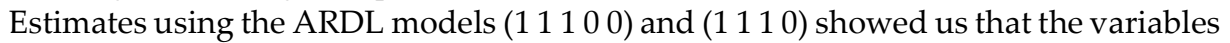
that are significant in the long run are business-friendly regulations, globalization, and entrepreneurship, but in the short term, none of the variables is considered statistically significant in the long term. Of the three significant variables, the one that most contributes to economic growth is business-friendly regulation, which again demonstrates its importance in economic growth. As for the variable economic freedom in this specific case, it is not considered significant, despite presenting a positive sign following what was expected.

Concerning economic freedom, the conclusions that were drawn for the Nordic countries in terms of positive effects on economic growth, do not exist in this specific case. Also, for the Nordic countries, the World Economic Forum advised policymakers to put more effort into administrative reductions for businesses thereby increasing economic freedom, despite these having already made progress [48]. Perhaps, for this reason, this variable does not assume statistical significance. On the other hand, some authors found empirical evidence that in some situations increases in economic freedom do not contribute to economic progress [7]. Because of the above, our hypothesis one is not confirmed.

As for business-friendly regulation, special attention should be paid to this variable, as it is the one that most impacts economic growth. This result is in line with that recommended by the World Bank, in which the countries with the highest scores in the EDB classification enjoy higher economic growth via higher productivity [49]. Lower entry costs encourage the emergence of new and better companies, reduce corruption, which leads to greater employment opportunities. In this way, the private sector has enhanced opportunities to develop more efficiently.

With the faster judicial dispute, the resolution of insolvency faster, the credit easier to obtain, and intellectual and industrial property is more and better protected [49]. In the 2020 edition, Denmark occupies the fourth place, Norway the ninth place, Sweden the tenth place, Finland the twentieth place, and Iceland the twenty-sixth place. In the 2010 edition, Denmark occupied the sixth place, Norway the tenth, Finland the sixteenth, Sweden the eighteenth, and Iceland fourteenth place. If we add up all the positions, in ten years these four Nordic countries (except Iceland) have increased seven positions in the ranking, which can also help to justify the contribution of this variable to economic growth.

Globalization is a variable and a theme that is increasingly present in the scientific literature. As Nordic countries are known for their "Nordic Welfares States" with high public sector participation, well-developed social security, and high levels of social solidarity with a focus on social parity and equal opportunities, one would expect that 
globalization would negatively affect the economic growth of these countries [50]. On the contrary, these countries are adapting perfectly to the globalization process because they are permanently investing in the educational system, in the health system, and in the increase of productivity, always being ahead of other nations, that allows them to maintain their living standard [51].

In the second half of the 20th century, the Nordic countries underwent rapid technoeconomic progress and are now the main drivers of industrial modernity, while achieving it in a socially sustainable way [52].

The Nordic countries have specificities not only from the historical and socio-cultural point of view but also from the perspective of entrepreneurship and their research, turning them very peculiar cases, to which many authors attribute the isolation caused by extreme geographical and climatic characteristics most of the year [53].

The entrepreneurship contributes significantly to economic growth, as has been noted by countless authors both for Nordic countries and for other geographies and already mentioned in the literature review, being still one of the factors that create jobs, innovation, technological progress, and competitiveness [24, 54 - 56].

Regarding the results verified using Granger's Causality, we found that they almost confirm the results obtained through the long-term ARDL methodology. As for the bidirectional causality between the variables, we found bidirectional causality between Business-Friendly regulations and Economic growth (as in the ARDL model), for Globalization and Economic growth (as seen in the ARDL model), Economic freedom and Businessfriendly regulations, Economic freedom, and Globalization, and finally, between Economic freedom and Entrepreneurship.

Also using Granger's Causality, we managed to obtain three unidirectional causal relationships, which were from Globalization to Business-friendly regulations, Globalization to Entrepreneurship, and from Entrepreneurship to Business-friendly regulations.

Concerning the potential causal relationship from the point of view of Granger's Causality to the relationship between entrepreneurship and GDPpc, we accept the null hypothesis that there is no causal relationship. This is the only difference between the results obtained between Granger's Causality and the long-term ARDL Methodology. Certainly, this result may not be very surprising, because, in the long-term ARDL model, the entrepreneurship variable is the one with the least statistical significance, with a very low coefficient. For a nonsignificant value, it reaches statistical significance to a level of $10 \%$. However, these three variables together contribute significantly to GDPpc growth.

These results are not surprising and have already been referred to, in a certain way, in the general literature and the specific literature on the Nordic countries. We must not forget, as we have already mentioned, that these indexes are built based on variables from validated scientific articles.

For 26 European Union countries using the two-stage least squares estimation method, in which the only two variables that coincide with this study are the EDB index and entrepreneurship but calculated by GEDI and not by Fraser as in this article, were similar results were achieved for the short term [56]. As in the present article, the EDB variable is not statistically significant, while in the cluster analysis, in the group composed of the Nordic countries of the EU, neither the EDB variable nor the entrepreneurship variable is significant. These two relevant conclusions are significant, as they reveal that both for the form of Panel IV used and for the short-term ARDL model, the conclusions are identical, for the case of the Nordic countries [57].

\section{Conclusions}

The main objective of this paper, using the ARDL methodology, is to study the effects that economic freedom, business-friendly regulation, globalization, and entrepreneurship tend to have on the economic growth of the Nordic countries. As these variables are difficult to measure, we use as proxies the most prestigious international indicators and widely used in scientific literature, for the period under study between 2004 and 2018. Then we resorted to Granger's Causality tests for robustness check. 
As the Nordic countries have the most goods listed in these indexes, have the progressions in these scores justified economic growth, and other countries can take this model as a reference? For the period in question, it is not confirmed that economic freedom is contributing to the economic growth of the Nordic countries, despite the coefficient showing a positive sign. In 2016, the World Economic Forum explicitly requested the Nordic countries to remove unnecessary administrative barriers established, and to new companies, to facilitate the execution of business. With the present study performed up to 2018, it appears that these obstacles persist. As one of the ultimate objectives of economic policies to achieve growth, to achieve this objective it is suggested that Nordic policymakers directly influence the factors that allow for the expansion of economic freedom, such as creating additional competitions in business and/or in the credit markets. Regarding the variable Economic freedom, Granger's causality confirms the result obtained through the ARDL methodology.

As in many geographies, in the Nordic countries' regulations favourable to streamlining business promote the realization of business. It is not a matter of facilitating deregulated business but giving legal and political institutions appropriate roles for business in more developed and participatory democracies [49]. The importance of this variable in the Nordic countries confirms the results obtained by several authors already mentioned in this study, in which countries with better rankings grow faster than the others [19]. In this way, policymakers should not abandon the models adopted in this variable and, if possible, should reinforce them. For example, through procedures that determine to reduce the time to start a business, register properties, decrease customs times in import processes, and in times of obtaining credit. Also, regarding this variable, Granger's Causality confirms the result obtained by the ARDL methodology.

The Nordic countries have obtained good economic results with the processes of increasing globalization, demonstrating a high resilience in face of this variable, since their welfare states have remained largely intact [12]. According to data from 2020, Sweden occupies fourth place with almost 90 points out of a possible 100, Denmark falls for eighth place with 88 points, Finland in the ninth position with 87.7 points, Norway occupies the twelfth position, and Iceland occupies the fiftieth position with 71.91 points in one ranking in which only the fifty most important countries in the world are analysed.

We recognize the good work that the Nordic countries have done to adapt to the inevitable globalization. They were one of the pioneers of this process when the first people of the Scandinavian region called Vikings arrived in a good part of the northern hemisphere, which in addition to barbaric attitudes, destruction and looting also practiced trade [58].

By constantly investing in the educational system, R\&D, and the health system, the Nordic countries are preparing their young people for the future, transmitting knowledge correctly, and preparing them for adulthood. Policymakers are advised to intensify these procedures so as not to be overtaken by other countries. Important points to guarantee advantages in the face of the lower costs of globalization is the permanent bet on innovation and productivity that allows maintaining the traditional standard of living in Nordic societies. The results obtained from Globalization by using the Granger Causality Test confirms the results obtained by the ARDL methodology.

Finally, concerning entrepreneurship, it can emerge as a corollary of all the variables that we studied previously and from there it was left to the last place. The entrepreneur enjoys a fundamental characteristic, namely, innovation [59]. If there is a positive response in the market to this innovation and the market has a favourable regulation for this business, conditions are created for the success of the product [60]. As most innovations are currently thought of in global markets, the virtuous circle between entrepreneurship and globalization is completed, through economic freedom and business-friendly regulation, without this virtuous circle occurring [61]. Fostering entrepreneurial clubs that at the beginning of their careers allow them to enjoy collective bargaining and support as a way of making their products and services more competitive is a valuable tool in the formation of a good business environment, social dialogue, consensual and mutually beneficial 
solutions that promote the competitiveness of the economy and its productivity since it exists in the Nordic countries a tradition of associative as a way to combat the isolation caused by the climate and the low demographic density. Regarding entrepreneurship, Granger's Causality does not validate the result obtained by the ARDL model, perhaps since in this model, the $10 \%$ of statistical significance is being obtained practically at the limit.

With the results obtained using Granger's Causality, the Nordic countries knew how to take advantage of globalization to obtain economic growth, perhaps particularly in terms of imports, and benefited from globalization to export more. Increases in globalization benefit the economic growth of the Nordic countries. It is also demonstrated that economic growth itself impacts three variables, two of which (Globalization and Entrepreneurship) cause a two-way causal relationship in each other, forming a virtuous circle.

This paper should raise awareness to policymakers to pay attention to the progress of international indices, because these in general cause economic growth, and cause growth in other variables that in themselves will enhance more economic growth in the future.

The Nordic countries have found a way to generate benefits for them from changes in economic and social variables, but without compromising their ways of life that allow them to achieve their sustainability, which they cost so much to obtain, either because of their geographical position or because of their climatic conditions.

Author Contributions: Conceptualization, M.C.N., and M.M.; investigation, M.C.N; methodology, M.C.N.; supervision, M.M.; writing - original draft, M.C.N.; writing-review and editing, M.M. All authors have read and agreed to the published version of the manuscript.

Funding: This research received no external funding.

Institutional Review Board Statement: Not applicable.

Informed Consent Statement: Not applicable.

Data Availability Statement: Data sharing not applicable.

Conflicts of Interest: The authors declare no conflict of interest.

\section{References}

1. Ervasti, H.; Fridberg, T.; Hjerm, M.; Kangas, O. Ringdal, M. Nordic Social Attitudes in a European Perspective, 2008. Northampton, USA: Edward Elgar.

2. Andreasson, U. Trust - The Nordic Gold. Copenhagen: Nordic Council of Ministers - Analysis Report, 2017.

3. Helliwell, J.; Layard, R.; Sachs, J.; Neves J. World Happiness Report 2020. 2020. Vancouver: Associate Editors: Lara B. Aknin, Haifang Huang, and Shun Wang.

4. Nikolaev, B.; Bennett, D. Give me liberty and give me control: Economic freedom, control perceptions and the paradox of choice, European Journal of Political Economy, 2016, 45, 39-52. doi.org/10.1016/j.ejpoleco.2015.12.002

5. Mandić, A., Petric, L.; Pivaevic, S. Film a creative industry constituent and its impacts on tourism development: Evidence from Croatia, ToSEE - Tourism in Southern and Eastern Europe, 2017, 4, 335-48. doi.org/10.20867/tosee.04.14

6. Compton, R.; Giedman, D.; Hoover, G. A distributional analysis of the benefits of economic freedom, European Journal of Political Economy, 2014, 33, 121-33. doi.org/10.1016/j.ejpoleco.2013.12.001

7. Hussain, E., and M. Haque (2016), "Impact of economic freedom on the growth rate: a panel data analysis", Economies, 4 (2), 1-15.

8. Miller, T.; Kim, A.; Roberts, J.; Tyrrel, P. Highlights of the 2020 index of Economic Freedom, 2020, Washington, DC: The Heritage Foundation. 
9. Brkic, I.; Gradojecic, N.; Ignjatijevic, S. The Impact of Economic Freedom on Economic Growth? New European Dynamic Panel Evidence, Journal of Risk and Financial Management, 202013 (2), 26. doi.org/10.3390/jrfm13020026

10. Almekinders, G.; Fukuda, S.; Mourmouras A. Zhou, J. Zhou, Y. ASEAN Financial Integration, Working Paper nº WP/15/34, 2015, International Monetary Found.

11. Bujanca, G.; Ulman, S. The impact of the economic freedom on national competitiveness in the main economic power centers in the world. Procedia Economics and Finance, 2015, 20, 94-103. doi.org/10.1016/S2212-5671(15)00052-0

12. Berg, A. Explaining Welfare State Survival: The Role of Economic Freedom and Globalization, 2006 https://papers.ssrn.com/sol3/papers.cfm?abstract_id=897746, accessed in 26 May 2021.

13. Iacobuta, A., and M. Ifrim (2020), "Welfare Mentality as a Challenge to European Sustainable Development. What Role for Youth Inclusion and Institutions?", Sustainability, 12 (3549).

14. Djankov, S.; La Porta, R.; Lopez-de-Silanes F. Shleifer, A. The Regulation of Entry, The Quarterly Journal of Economics, 2002, 117 (Issue 1), 1-37. doi.org/10.1162/003355302753399436

15. Gillanders, R. and K. Whelan (2014), "Open for business? Institutions, business, environment and economic development", Kyklos, 67 (4), 535-58.

16. Haidar, J. The impact of business regulatory reforms on economic growth, Journal of the Japanese and International Economies, 2012. 26 (3), 285-307. doi.org/10.1016/j.jjie.2012.05.004

17. Pere, E.; Hashorva, A. Business regulation and economic growth in the Western Balkan Countries, Eastern Journal of European Studies, 2013, 4 (1), 5-15.

18. Corcoran, A.; Gillanders, R. Foreign direct investment and the ease of doing business, Review of World Economics, 2015, 151 (1), 103-26. doi.org/10.1007/s10290-014-0194-5

19. Leal-Rodriguez, A.; Sanchis-Pedregosa, C. Could the Ease of Doing Business be considered a predictor of countries'SocioEconomic wealth?, An empirical analysis using PLS-SEM, Journal of International Studies, 2019, 12 (4), $229-43$. DOI: $10.14254 / 2071-8330.2019 / 12-4 / 15$

20. Tan, K.; Amri, M.; Merdikawati, N. A new index to measure ease of doing business at the sub-national level. Empirical findings from Indonesia. Cross Cultural \& Strategic Management, 2018, 25 (3), 515-37. doi.org/10.1108/CCSM-01-2017-0009

21. Jayasuriya, D. (2011), "Improvements in the World Bank`s ease of doing business rankings: do they translate into greater foreign direct investment inflows", Policy Research Working Papers.

22. Cui, X.; Yao, Y.; Bian, Y.; Cui, L. Can better bussiness environment promote trade partener's economic growth?, Applied Economic Letters, 2021, 1-5, doi.org/10.1080/13504851.2021.1875115

23. Anderson, T.; Holmstroom, B.; Honkapohja, S.; Korkman, S.; Soderstrom, T.; Vartiainen, J. The Nordic Model - Embracing globalization and sharing risks, Helsinki: The Research Institute of the Finnish Economy (ETLA), 2007.

24. Dvoulety, O. Determinants of Nordic entrepreneurship, Journal of Small Business and Enterprise, 201724 (1), $12-33$. doi.org/10.1108/JSBED-07-2016-0104

25. Allern, S.; Pollack, E. The Role of Think Tanks in the Swedish Political Landscape, Scandinavian Political Studies, 2020, 43 (3), 14569. doi.org/10.1111/1467-9477.12180

26. Gurgul, H.; Lach, L. Globalization and economic growth: Evidence from two decades of transition in CEE. Economic Modeling, 2014. 36, 99-107. doi.org/10.1016/j.econmod.2013.09.022

27. Dreher, A.; Gasto, N.; Martens. Measuring globalisation - gauging its consequences, 2008, New York: Spring.

28. Mjoset, L. Nordic economic policies in the 1970s and 1980s, International Organization, 1987, 41 (3), $403-56$. doi.org/10.1017/S0020818300027533

29. Nielsen, K.; Kesting, S. Small is Resilient - The impact of Globalization on Denmark, Review of Social Economy, 2013, 6 (3), 365-387. doi.org/10.1080/0034676032000115822 
30. Fellman, S. Economic Development in the Nordic countries. 2019. Accessed in https://nordics.info/show/artikel/economicdevelopment-in-the-nordic-countries/

31. Klapper, L.,; Love. L. The impact of Business Environment Reforms on New Firm Registratio, 2010. World Bank Policy Research Working Paper, Number 5493.

32. Nogueira, M.; M. Madaleno. New evidence of competitiveness based on the global competitiveness index, Economics Bulletin, 2021a 41 (2), 788-97.

33. Corbetta, G.; Huse, M.; Ravasi, D. Crossroads of entrepreneurship, 2004, New York: Klumer Academic Publishers.

34. Chiu, R. Entrepreneurship education in the Nordic Countries - Strategy implementation and good practices, 2012, Oslo: Nordic Innovation Publication.

35. Medeiros, V.; Marques, C.; Galvão, A.; Braga, V. Innovation and entrepreneurship as drivers of economic development: Differences in European economies based on quadruple helix model, Competitiveness Review, 2020, 30 (5), 681-704. doi.org/10.1108/CR-08-2019-0076

36. Gujarati, D. Basic Econometrics, 4 th Edition. 2002. New York: McGraw- Hill.

37. Granger, C. . Some properties of times series data and their use in econometric model specification, Journal of Econometrics, 1981. 28, 121-130.

38. Engle, R.; Granger, C. (1987), "Cointegration and error correction: Representation, estimation and testing", Econometrica, 55, 251276.

39. Pesaran, M.; Shin, Y. Generalized impulse response analysis in linear multivariate models, Economics Letters, 1998, 58 (1), 17-29. doi.org/10.1016/S0165-1765(97)00214-0

40. Pesaran, M.; Shin, Y.; Smith, R. Bounds testing approaches to the analysis of level relationship, Journal of Applied Econometrics, 2001, 16, 289-326. doi.org/10.1002/jae.616

41. Jali, A., and Y. Ma (2008), "Financial development and economic growth: times series evidence from Pakistan and China", Journal of Economic Cooperation, 29 (2), 29-68.

42. Samagardi, N.; Fidrmuc, J.; Ghosh, S. Financial development and economic growth in an oil-rich economy: The case of Saudi Arabia, Economic Modelling, 2014, 43, 267-78. doi.org/10.1016/j.econmod.2014.07.042

43. Nkoro, E.; Uko, A. Autoregressive Distributed Lag (ARDL) cointegration technique: application and interpretation, Journal of Statistical and Econometric Methods, 2016, 5 (4), 63-91.

44. Akaike, H. A new look at the statistical model identification, IEEE Transactions on Automatic Control, 1974, 716-723

45. Pesaran, M.; Pesaran, A. Working with Microsoft 4.0: Interactive Econometric Analysis, 1997 Oxford: Oxford University Press.

46. Granger, C. Investigating causal relations by econometric models and cross-spectral methods, Econometrica, 1969, 37, 424-38. doi.org/10.2307/1912791

47. Toda, H.; Yamamoto, Y. Statistical Inferences in Vector autoregression possibly integrated process, Journal of Economics, 1995, 66, 225-50. doi.org/10.1016/0304-4076(94)01616-8

48. World Economic Forum, Global Competitiviness Report. 2016. Geneva: World Economic Forum.

49. World Bank, Doing Business 2019, 2019 Washington: A World Bank Group.

50. Ahl, H.; Berglund, K.; Pettersson, K.; Tilmar, M. From feminism to FemInc.ism: On the uneasy relationship between feminism, entrepreneurship and the Nordic welfare state. International Entrepreneurship and Management Journal, 2016, 12, 369-392. doi.org/10.1007/s11365-014-0341-4

51. Baghirzade, N. Can the welfare state be the future of the global economy? Network Intelligence Studies, 2020, 15 (1), 45-5.

52. Witoszek, N.; Midtturn, A. Sustainable Modernity The Nordic Model and Beyond. 2018. Routledge, New York.

53. Kuckertz, A.; Berger, E.; Allmendinzer, M. A Configurations Analysis of the Determinants of Entrepreneurship in InnovationDriven Economies, Business Administration Review, 2015, 75 (4), 273-88. 
54. Prasetyo, P.; Kistanti, N. Human Capital, Institutional Economics and Entrepreneurship as a Driver for Quality \& Sustainable Economic Growth. Entrepreneurship and Sustainability Issues, 2020, 7 (4), 2575-89. doi.org/10.9770/jesi.2020.7.4(1)

55. Du, K.; O`Connor, A. Entrepreneurship and advancing national level economic efficiency, Small Business Economics, 2018, 50, 91-111. doi.org/10.1007/s11187-017-9904-4

56. Fernandes, C.; Veiga, P.; Ferreira, J.; Teixeira, S.; Rammal, H. The Impact of Innovation and Entrepreneurship on competitiveness, Technological Innovation and International Competitiviness for Business Growth, Palgrave Studies in Democracy, Innovation, and Entrepreneurdhip for Growth, Palgrave, 2021, Nacmillan, 97-117.

57. Nogueira, M.; M. Madaleno. Are International Indices Good Predictors of Economic Growth? Panel Data and Cluster Analysis for European Union Countries, Sustainability, 2021b, 13 (6003). doi.org/10.3390/su13116003

58. Jones, G. (2001), "A History Of the Vikings". New York: Oxford University Press.

59. Schumpeter, J. The theory of economic development - An inquiry into profits, capital, credit, interest and business cycle (1934), (1983) Cambridge, MA: Harvard University Press.

60. Ács, Z.; Szerb, L. The Global Entrepreneurship Index (GEINDEX). Washington, DC: Foundation and Trends in Entrepreneurship, 2009.

61. Coulibaly, S.; Erbao, C.; Mekongcho, M. Economic globalization, entrepreneurship and development, Technological Forecasting E Social Change, 2018, 127, 271-80. doi.org/10.1016/j.techfore.2017.09.028 